Zambia, while open to researchers, has been burned enough in various ways, e.g., time of public officials consumed, that both institutes actively restrict the number of researchers coming into Zambia. The Institute of African Studies has identified priority problem areas for research (write the Director for a list). The Rural Development Studies Bureau prefers local case studies rather than exploration of national policy processes or issues. Two criteria appear to be critical for approval: 1) explicit government needs, and 2) the academic quality of the project. The institutes grant research affiliate status when they approve a project.

Visas: All countries automatically issue short term vises to American citizens at ports of entry. With the exception of Zambia, the application for an extended research visit is probably best submitted after arrival. For Zambia, the researcher should obtain the necessary study permit from Immigration before arrival. About a month is required for processing of papers. The two institutes provide the appropriate forms and institutional support.

\title{
LETTER/U.N. COUNCIL FOR NAMIBIA
}

African Studies Association

31 January 1979

Brandeis University

Epstein Service Building

Waltham, Massachusetts 02154

Dear Sir/Madam,

As you may be aware, the General Assembly of the United Nations terminated in 1966 the mandate exercised by South Africa over the Territory of Namibia, formerly South West Africa. The decision of the General Assembly was endorsed by the Security Council and the International Court of Justice. The action of the General Assembly was determined by the refusal of South Africa to recognize the authority of the United Nations to determine the establishment of a trusteeship agreement to replace the mandate created by the League of Nations. In 1967, the General Assembly created the United Nations Council for Namibia to administer the Territory, with the maximum participation of the inhabitants, and assist its people until independence.

South Africa has continuously refused to comply with all United Nations resolutions on Namibia. The Council for Namibia has therefore carried out intensive efforts to mobilize the international community to press for the withdrawal of the illegal South African administration from Namibia. As part of its activities it has formulated a policy of systematic dissemination of information on all aspects of the question of Namibia including the liberation struggle waged by the Namibian people under the leadership of their sole and authentic liberation movement, SWAPO, to achieve selfdetermination, freedom and national independence in a united Namibia.

The United Nations Council for Namibia intends during 1979 to step up its programme of dissemination of information amongst leading opinion makers, in the information media, in political and academic institutions, and in other concerned non-governmental organizations. This programme is, inter alia, to take the form of small missions of the Council to institutions or organizations which would invite the Council for an exchange of views with regard to the question of Namibia and its illegal occupation by South Africa. In this context, the Council attaches great importance to a wellinformed public opinion and the role of the media in assisting the efforts of the Council to bring a speedy end to the illegal occupation of Namibia by South Africa.

The proposed topics of discussion in formal or informal talks, television appearances, press interviews, lectures, panel debates and other appearances would include, amongst others the following:

(1) the genesis, objectives and functions of the United Nations Council for Namibia;

(2) the history and struggle of the Namibian people under the leadership of SWAPO, and the role played by the United Nations;

(3) the political, social, and military aspects of the illegal occupation of Namibia by South Africa and the role of multinational corporations and their support for the illegal South African administration in Namibia.

In addition to these topics, the delegation would welcome any other suggestions from interested institutions and organizations. 
Transportation and hotel costs of the delegations of the Council will be borne by the Council. It would be greatly appreciated, however, if the host institution or organization could arrange for local transportation and reservations of hotel accommodation.

The Council also intends to invite all interested personalities and academicians within various institutions, organizations and the media to appear before special meetings of the Council and make statements relevant to the work of the Council. It would be expected that those who address the Council accept to participate in a question-and-answer period after any statement is made.

The Council for Namibia would appreciate receiving your comments regarding the interest of your institution or organization to participate in the activities of the Council described above.

Yours truly,

Paul Lusaka

President

United Nations Council for Namibia

(Room 3310, United Nations, New York)

\section{OBITUARY}

\section{RUPERT EMERSON}

Rupert Emerson, President of the African Studies Association in 1965-66, died on Friday, February 9. Professor Emerson was one of the pioneers of modern area studies in this country, having published his first book on European colonialism more than forty years ago. His first book on colonialism, Malaysia: $A$ Study in Direct and Indirect Rule, was published in 1937. This book was followed by The Netherlands Indies and the United States, published in 1942. One of Emerson's unique distinctions was to have served as President of two area studies associations. Before becoming President of the ASA, he held that office in the Far Eastern (Studies) Association in 1952-53. He has been a Professor of Government at Harvard University for more than forty years before he retired in 1970. While there, he educated a generation of scholars in various area studies fields including such persons as Karl Deutsch, James Colemen, Martin Kilson, and Robert Scalapino. Emerson's major study of the transition from colonial rule to independence, From Empire to Nation, is now considered a classic and students of Africa as well as other developing areas continue to find his analysis of penetrating originality and importance. After his retirement from Harvard, Emerson taught for several years in the Political Science Department at the University of California, Los Angeles and was associated, while there, with the African Studies Center.

Michael Lofchie 